\title{
The Optimal Policy Mix to Achieve Public Debt Consolidation*
}

\author{
Roberta Cardani ${ }^{\dagger}$ \\ University of Pavia
}

\author{
Lorenzo Menna ${ }^{\ddagger}$ \\ Banco de Mexico
}

\author{
Patrizio Tirelli ${ }^{\S}$ \\ University of Milano-Bicocca
}

December 29, 2016

\begin{abstract}
In this paper we adopt a Ramsey-optimal approach to identify the combination of income taxes, public expenditure and inflation designed to achieve a fiscal consolidation. In contrast with empirical contributions that emphasize the benefits of expenditure based consolidations, the optimal policy calls for increases in taxes and inflation. Strong monetary accommodation is quite beneficial relative to a situation where the Central Bank is only concerned with inflation stability and the inflation target is defined as a ceiling, as in the Eurozone.

JEL codes: E32, E62, E63

Keywords: Fiscal Consolidation, Limited Asset Market Participation, Ramsey Fiscal Policy
\end{abstract}

${ }^{*}$ Cardani and Tirelli are gratefully acknowledges financial support from EC project 320278- RASTANEWS funded by the European Community's 7th Framework Program (FP7).

${ }^{\dagger}$ Department of Economics and Management, University of Pavia, via San Felice, 5, 27100 Pavia, Italy. Email: roberta.cardani@unipv.it

¥Directorate General of Financial Stability of Banco de Mexico, Avenida 5 de Mayo 2, Ciudad de México, México. Email: lorenzo.menna@banxico.org.mx. The views expressed are those of the individual author and do not necessarily reflect official positions of the Banco de Mexico.

$\S$ DEMS, University of Milano-Bicocca, Piazza dell'Ateneo Nuovo 1, 20126 Milano, Italy. Email: patrizio.tirelli@unimib.it. 


\section{Introduction}

Following the large increases in public-debt-to-GDP ratios observed in the aftermath of the 2007financial crisis, fiscal consolidation, i.e. a reduction in the debt-to-GDP ratio, has come to the forefront of political debate and macroeconomic analyses (Blanchard et al., OECD 2012). The issue is particularly relevant for the Eurozone, where institutional arrangements such as the Maastricht Treaty and the Stability and Growth Pact (SGP) should oblige member states to pursue a $60 \%$ debt-to-GDP ratio. In fact the 'corrective arm' of the SGP should be activated whenever public debt exceeds $60 \%$ of GDP and the excess debt is not reduced by $5 \%$ per year on average over three years (European Commission).

Empirical research emphasizes the importance of achieving fiscal consolidation through public expenditures reductions (Nickel, Rother and Zimmermann, 2010; Alesina, Favero and Giavazzi, 2015), but it is no longer supporting the view that fiscal consolidations may be expansionary provided that they are based on public expenditure reductions (Perotti, 2011). It is now widely acknowledged that fiscal consolidation causes output losses in the short run, and there is a growing concern with the distributional consequences of fiscal consolidations (OECD, 2013). One less investigated issue is whether inflation targets should be temporarily raised to facilitate public debt reduction (Rogoff, 2010; Aizenman and Marion, 2011).

A growing body of theoretical literature has analyzed the issue of debt reductions in the context of DSGE models where fiscal policy makers implement simple feedback rules for tax and expenditure variables, whereas the Central Bank implements a standard Taylor rule. Coenen, Mohr and Straub (2008) model the fiscal consolidation as a permanent reduction in the target for the debt-to-output ratio that enters into the feedback rules, showing that public debt reductions involve tradeoffs between short-run losses and long-run benefits. Note that short run adverse effects are mainly borne by households whose ability to smooth consumption is impaired by their limited participation to asset markets. Ferrara and Tirelli (2014) adopt a similar approach to investigate which policy mix, including targeted public transfers and an accommodative monetary policy, could be adopted to avoid the adverse redistributive effects of fiscal consolidations. Philippopoulos et al. (2015) neglect distributive issues and focus on the optimization of feedback rules, i.e. on the choice of feedback parameters that maximize the representative household's expected discounted lifetime utility for given exogenous debt and inflation targets.

In this paper we adopt a Ramsey-optimal approach to the identification of debt reduction strategies, that is, we identify the optimal policy mix for income taxes, public expenditures and inflation designed to achieve an exogenous debt reduction path as envisaged, for instance, in the Stability and Growth Pact. There is a number of questions the paper is meant to address. The first one concern the optimal combination of public expenditure reductions and tax increases. In this regard, to avoid trivial results and in contrast with authors such as Forni et al. (2010), we assume that public consumption is not a mere dissipation of resources but generates utility to households, as in Stahler and Thomas (2012) and Ferrara and Tirelli (2014). The second one relates to the desirability of adjusting the inflation target during the debt consolidation period. To this end our model incorporates a monetary transactions technology that follows Schmitt-Grohé and Uribe (2011, SGU henceforth). As a result, in our model we can identify the optimal inflation rate both in the pre-consolidation steady state and during the transition to the low public debt steady state. To better understand the importance of exploiting inflation to facilitate consolidation, we shall also consider an alternative strategy of debt consolidation, where the Central bank sticks to an inflation targeting policy and the responsibility for debt consolidation rests in the hands of 
the fiscal policymaker. The relevance of this issue for the EMU situation is self-apparent given the institutional arrangements that prohibit monetary financing (Article 123 of the Treaty on the Functioning of the European Union). Finally, the third question we address concerns redistributive effects of alternative policies. To capture these effects our model accounts for Limited Asset Market Participation (LAMP henceforth), that is, a fraction of households do not own interest bearing assets and can only exploit their money holdings to smooth consumption during the transition, as in Coenen, Mohr and Straub (2008).

Our results in a nutshell. We find that consolidations entail a persistent tax (public expenditure) increase (reduction). We also find that inflation follows a hump-shaped pattern, raising up to 2 percentage points above the pre-consolidation level. The consolidation is associated to a sharp reduction in investment and to a milder but persistent reduction in aggregate consumption. Output remains below the pre-consolidation level throughout the transition to the new debt-to-GDP ratios, and the consumption gains associated to the consolidation begin to materialize only after consolidation is achieved. We also identify important redistributive effects. Wealthy capital owners exploit the reduction in investment expenditures to stabilize their consumption. In addition, they reduce their labor supply in response to the increase in labor taxation. When monetary policy is not involved in the consolidation exercise and the central bank sticks to her inflation targeting strategy the fiscal contraction is inevitably stronger and the output loss much larger. Constrained households bear the brunt of this alternative policy strategy, suffering a deeper reduction in consumption.

The rest of the paper is organized as follows. Section 2 presents the model. Section 3 describes the competitive equilibrium and defines the Ramsey optimal policy. In section 4 we obtain the steady state results. Section 5 describes the optimal Ramsey dynamics and section 6 concludes.

\section{The model}

We consider a standard DSGE model characterized by monopolistic competition and nominal rigidities in the goods and labor markets. Following Schmitt-Grohé and Uribe (2004a), monetary transaction costs are introduced in order to motivate a demand for money:

$$
s_{t, i}=A v_{t, i}+\frac{B}{v_{t, i}}-2 \sqrt{A B}
$$

where $v_{t, i}=\frac{c_{t, i}}{m_{t, i}}$ defines money velocity, $c_{t, i}$ is household's $i$ real consumption, $m_{t, i}=\frac{M_{t, i}}{P_{t, i}}$ denotes real money balances. Note that

$$
s^{\prime}\left(v_{t, i}\right)>0 \text { for } v_{t, i}>v^{*} ; v^{*}>0
$$

$v^{*}>0$ defines a satiation level for money velocity because at $v_{t, i}=v^{*}$ the transaction cost is nil. Note that $\frac{c_{t, i}}{m_{t, i}}=v^{*}$ is associated to a zero nominal interest rate.

Households utility function is

$$
U=E_{0} \sum_{t=0}^{\infty} \beta^{t} u\left(c_{t}^{i}, l_{t}^{i}, g_{t}\right)=\ln c_{t}^{i}+\eta \ln \left(1-l_{t}^{i}\right)+\xi \ln g_{t}
$$

where $\beta$ is the subjective discount rate and $l_{t}^{i}$ denotes supply of a differentiated labor type. A fraction $\theta \in[0,1]$ of households only participates in the money market and does not hold any 
other asset (henceforth constrained or non-Ricardian agents, $c$ ). The remaining $1-\theta$ fraction of households have full access to financial markets and own firms (henceforth unconstrained or Ricardian agents , $u$ ).

The government finances expenditures by levying distortionary income taxes and by printing money. Optimal policy is set according to a Ramsey plan. Right from the outset, note that we rule out production subsidies as well as lump-sum taxes because use of these instruments allows to obtain efficient outcomes that would be difficult to reach in more complex and more realistic settings. Similarly, consumption taxation would improve efficiency and allow to address distributional issues only if it were supplemented by individually targeted public transfers (Correia 2010). ${ }^{1}$ Finally, to sharpen our focus on the trade-offs between distortionary taxation, public consumption and inflation as tools to achieve the fiscal consolidation, we posit that factor incomes are taxed at a unique income tax rate. This would certainly be a serious shortcoming if we were concerned with optimal tax structure in steady state, but it seems a lesser problem when the focus is on transitional dynamics during the consolidation episode. ${ }^{2}$

\subsection{Labor Packers}

Firms use a labor bundle, $l_{t}^{d}$, as a production factor. Such bundle is produced by labor packers who buy the households supply their differentiated labor services to labor packers who assemble the labor bundle

$$
l_{t}^{d}=\left[\int_{0}^{1}\left(l_{t}^{i}\right)^{\rho_{w}} d i\right]^{\frac{1}{\rho_{w}}}
$$

Under perfect competition, labor packers solve the following problem:

$$
\max w_{t} l_{t}^{d}-\int_{0}^{1} w_{t}^{i} l_{t}^{i} d i
$$

subject to (4). The demand function for labor type $i$ therefore is

$$
l_{t}^{i}=l_{t}^{d}\left(\frac{w_{t}^{i}}{w_{t}}\right)^{\frac{1}{\rho_{w}-1}}
$$

and the wage index is $w_{t}=\left[\int_{0}^{1}\left(w_{t}^{i}\right)^{\frac{\rho_{w}}{\rho_{w}-1}} d i\right]^{\frac{\rho_{w}-1}{\rho_{w}}}$.

\subsection{Households}

Ricardian households are subject to the following period budget constraint

$$
\begin{gathered}
c_{t}^{u}\left(1+s_{t}\right)+\left(k_{t}^{u}-k_{t-1}^{u}\right)+\frac{M_{t}^{u}}{P_{t}}+\frac{B_{t}^{u}}{P_{t}}=\left(1-\tau_{t}^{l}\right) w_{t}^{u} l_{t}^{u}+\left(1-\tau_{t}^{k}\right)\left(r_{t}^{k}-\delta\right) k_{t-1}+ \\
+\frac{M_{t-1}^{u}}{P_{t}}+\frac{\Pi_{t}^{u}}{P_{t}}+\frac{R_{t-1} B_{t-1}^{u}}{P_{t}}-\frac{\xi_{w}}{2} l_{t}^{u}\left(\frac{w_{t}^{u} \pi_{t}}{w_{t-1}^{u}}-1\right)^{2}
\end{gathered}
$$

\footnotetext{
${ }^{1}$ Krusell et al. (1996) explain why use of consumption taxes in place of income taxes may be politically unfeasible.

${ }^{2}$ It would be straightforward that in this class of models the optimal capital income tax is be close to zero or even negative, where the need to offset monopolistic distortions in the goods market calls for negative taxation, but distributional concerns induce the planner to raise it. In any case labor and capital income taxes would be positively related during the debt reduction phase. Results available upon request.
} 
where $M_{t}^{u}$ defines nominal money holdings, $B_{t}^{u}$ is a one-period nominally riskless bond that pays one unit of currency, $k_{t}^{u}$ denotes the capital stock, $r_{t}^{k}$ is the rental rate of capital, $\delta$ is the depreciation rate, $\tau_{t}^{l}$ and $\tau_{t}^{k}$ respectively define the labor and capital-income tax rates. ${ }^{3} R_{t}$ is the gross nominal interest rate, $\pi_{t}=\frac{P_{t}}{P_{t-1}}$ is the gross inflation rate, $\Pi_{t}$ are nominal firms profits. Parameter $\xi_{w}$ identifies Rotemberg nominal wage adjustment costs, defined in terms of real output.

The representative constrained household is subject to the flow budget constraint

$$
c_{t}^{c}\left[1+s\left(\frac{P_{t} c_{t}^{c}}{M_{t}^{c}}\right)\right]+\frac{M_{t}^{c}}{P_{t}}=\left(1-\tau_{t}^{l}\right) w_{t} l_{t}^{c}+\frac{M_{t-1}^{c}}{P_{t}}-\frac{\xi_{w}}{2} l_{t}^{c}\left(\frac{w_{t}^{c} \pi_{t}}{w_{t-1}^{c}}-1\right)^{2}
$$

Solving the optimization problem for each group one obtains that the following first-order conditions are identical for all households:

$$
\begin{gathered}
\lambda_{t}^{i}=\frac{u_{c}\left(c_{t}^{i}, l_{t}^{i}\right)}{1+s\left(v_{t, i}\right)+v_{t, i} s^{\prime}\left(v_{t, i}\right)} \\
1-E_{t}\left[\frac{\beta}{\pi_{t+1}} \frac{\lambda_{t+1}^{i}}{\lambda_{t}^{i}}\right]=s^{\prime}\left(v_{t}^{i}\right)\left(v_{t}^{i}\right)^{2} \\
\frac{\left(w_{t}^{i} \rho_{w}+\frac{u_{l}\left(c_{t}^{i}, l_{t}^{i}\right)}{\left(1-\tau_{t}^{l}\right) \lambda_{t}^{i}}\right)\left(\frac{w_{t}^{i}}{w_{t}}\right)^{\frac{1}{\rho_{w}-1}}}{1-\rho_{w}}+\xi_{w} \frac{w_{t}^{i} \pi_{t}}{w_{t-1}^{i}}\left(\frac{w_{t}^{i} \pi_{t}}{w_{t-1}^{i}}-1\right)= \\
\beta E_{t}\left\{\frac{l_{t+1}^{i} \lambda_{t+1}^{i}}{l_{t}^{i} \lambda_{t}^{i}} \xi_{w}\left[\frac{w_{t+1}^{i} \pi_{t+1}}{w_{t}^{i}}\left(\frac{w_{t+1}^{i} \pi_{t+1}}{w_{t}^{i}}-1\right)\right]\right\}
\end{gathered}
$$

As shown in Schmitt-Grohé and Uribe (2004a), in (8) the transaction costs introduce a wedge between the marginal utility of consumption, $u_{c}\left(c_{t}^{u}, l_{t}^{u}\right)$, and the marginal utility of wealth, $\lambda_{t}^{u}$, that vanishes only if $\frac{c_{t}^{u}}{m_{t}^{u}}=v_{t}^{u}=v^{*}$. Equation (10) represents the standard wage setting equation. Finally, equation (9) describes an implicit money demand function.

Asset market participation allows to characterize two additional first-order conditions:

$$
\begin{gathered}
\lambda_{t}^{i}=\beta E_{t}\left(\frac{\lambda_{t+1}^{i} R_{t}}{\pi_{t+1}}\right) \\
\lambda_{t}^{i}=\beta E_{t}\left\{\lambda_{t+1}^{i}\left[\left(1-\tau_{t+1}^{k}\right)\left(r_{t+1}^{k}-\delta\right)+1\right]\right\}
\end{gathered}
$$

that define the Euler equations with respect to bonds and to physical capital.

Note that taking into account (11), from (9) one obtains the familiar relationship between money velocity and the nominal interest rate that in our model only characterizes money demand for unconstrained households.

$$
1-\frac{1}{R_{t}}=s^{\prime}\left(v_{t}^{u}\right)\left(v_{t}^{u}\right)^{2}
$$

Condition (13) allows to clarify a fundamental distinction between unconstrained and constrained households. In fact the inverse of the nominal interest rate defines the opportunity cost

\footnotetext{
${ }^{3}$ We assume that the government grants depreciation tax allowances.
} 
of holding money for unconstrained households, whose consumption decisions are driven by the expected real interest rate in (11). By contrast, constrained households cannot base their consumption decisions on returns from interest bearing assets. As a result, for these households the opportunity cost of holding money is $E_{t}\left[\frac{\beta}{\pi_{t+1}} \frac{\lambda_{t+1}^{c}}{\lambda_{t}^{c}}\right]$. Thus money demand is affected by expected inflation. ${ }^{4}$

Further, the money demand equation (9) can also be interpreted as an Euler equation driving consumption decisions for constrained households:

$$
\begin{gathered}
1-E_{t}\left[\frac{\beta}{\pi_{t+1}} \frac{\lambda_{t+1}^{c}}{\lambda_{t}^{c}}\right]=s^{\prime}\left(v_{t}^{c}\right)\left(v_{t}^{c}\right)^{2} \\
c_{t}^{c}=\left\{\frac{\pi_{t+1}\left[1-s^{\prime}\left(v_{t}^{c}\right)\left(v_{t}^{c}\right)^{2}\right]\left[1+s\left(v_{t+1, i}^{c}\right)+v_{t+1}^{c} s^{\prime}\left(v_{t+1}^{c}\right)\right]}{\beta\left[1+s\left(v_{t}^{c}\right)+v_{t, i}^{c} s^{\prime}\left(v_{t}^{c}\right)\right]}\right\} E_{t} c_{t+1}^{c}
\end{gathered}
$$

We discussing transition dynamics during the consolidation exercise we will show that inflation may have an important effect in stabilizing their consumption.

By contrast the Euler equation (11) for unconstrained households reads as follows

$$
c_{t}^{u}=\left\{\frac{\pi_{t+1}\left[1+s\left(v_{t+1}^{u}\right)+v_{t+1}^{u} s^{\prime}\left(v_{t+1}^{u}\right)\right]}{\beta R_{t}\left[1+s\left(v_{t}^{u}\right)+v_{t, i}^{u} s^{\prime}\left(v_{t}^{u}\right)\right]}\right\} E_{t} c_{t+1}^{u}
$$

Finally, from (10) it is easy to see that wage-setting decisions are identical for households belonging to the same group. Therefore

$$
w_{t}=\left[\int_{0}^{1}\left(w_{t}^{i}\right)^{\frac{\rho_{w}}{\rho_{w}-1}} d i\right]^{\frac{\rho_{w}-1}{\rho_{w}}}=\left[(1-\theta)\left(w_{t}^{u}\right)^{\frac{\rho_{w}}{\rho_{w}-1}}+\theta\left(w_{t}^{c}\right)^{\frac{\rho_{w}}{\rho_{w}-1}}\right]^{\frac{\rho_{w}-1}{\rho_{w}}}
$$

Similarly, equation (4) can be rewritten as

$$
l_{t}^{d}=\left[(1-\theta)\left(l_{t}^{u}\right)^{\rho_{w}}+\theta\left(l_{t}^{c}\right)^{\rho_{w}}\right]^{\frac{1}{\rho_{w}}}
$$

\section{$2.3 \quad$ Firms}

Monopolistically competitive intermediate firms produce differentiated goods, $z \in(0,1)$. Their production function is:

$$
y_{t}(z)=l_{t}(z)^{\alpha} k_{t-1}(z)^{1-\alpha}
$$

Pricing decisions for intermediate goods are subject to a quadratic cost of nominal price adjustment (Rotemberg (1982)):

$$
\frac{\xi_{p}}{2} y_{t}(z)\left[\frac{P_{t}(z)}{P_{t-1}(z)}-1\right]^{2}
$$

\footnotetext{
${ }^{4}$ Note that money-to consumption ratios for the two groups are identical in steady state, when $\frac{\lambda_{t+1}^{u}}{\lambda_{t}^{u}}=\frac{\lambda_{t+1}^{c}}{\lambda_{t}^{c}}=1$ and $R=\frac{\pi}{\beta}$.
} 
Demand for intermediate goods originates from perfectly competitive final good who assemble the final good bundle, $y_{t}^{d}=\left[\int_{0}^{1} y_{t}(z)^{\rho} d z\right]^{\frac{1}{\rho}}$. Thus each intermediate firm is confronted with the following demand function:

$$
y_{t}^{d}(z)=y_{t}^{d}\left[\frac{P_{t}(z)}{P_{t}}\right]^{\frac{1}{\rho-1}}
$$

where $P_{t}=\left[\int_{0}^{1} P_{t}(z)^{\frac{\rho}{\rho-1}} d z\right]^{\frac{\rho-1}{\rho}}$ is the price index.

In the intermediate goods sector the standard Phillips curve obtains:

$$
\frac{\left(\rho-m c_{t}\right)}{1-\rho}+\xi_{p} \pi_{t}\left(\pi_{t}-1\right)=\beta E_{t}\left\{\frac{y_{t+1}^{d} \lambda_{t+1}^{u}}{y_{t}^{d} \lambda_{t}^{u}} \xi_{p}\left[\pi_{t+1}\left(\pi_{t+1}-1\right)\right]\right\}
$$

where $m c_{t}$ are the real marginal costs. Factor demands are:

$$
\begin{gathered}
w_{t}=a_{t} \alpha m c_{t}\left(\frac{l_{t}}{k_{t-1}}\right)^{\alpha-1} \\
r_{t}^{k}=a_{t}(1-\alpha) m c_{t}\left(\frac{l_{t}}{k_{t-1}}\right)^{\alpha}
\end{gathered}
$$

\subsection{Aggregation}

Equations (23)-(27) define aggregate consumption, aggregate hours, aggregate real money balances, bonds, profits, aggregate capital and total output:

$$
\begin{gathered}
c_{t}=(1-\theta) c_{t}^{u}+\theta c_{t}^{c} \\
m_{t}=(1-\theta) m_{t}^{u}+\theta m_{t}^{c} \\
B_{t}^{u}=\frac{B_{t}}{1-\theta} \\
k_{t}^{u}=\frac{k_{t}}{1-\theta} \\
y_{t}^{d}=(1-\theta)\left[1+s\left(\frac{c_{t}^{u}}{m_{t}^{u}}\right)\right] c_{t}^{u}+\theta\left[1+s\left(\frac{c_{t}^{c}}{m_{t}^{c}}\right)\right] c_{t}^{c}+k_{t}-(1-\delta) k_{t-1}+ \\
g_{t}+\frac{\xi_{p}}{2} y_{t}\left(\pi_{t}-1\right)^{2}+(1-\theta) \frac{\xi_{w}}{2} l_{t}^{u}\left(\frac{w_{t}^{u} \pi_{t}}{w_{t-1}^{u}}-1\right)^{2}+\theta \frac{\xi_{w}}{2} l_{t}^{c}\left(\frac{w_{t}^{c} \pi_{t}}{w_{t-1}^{c}}-1\right)^{2}
\end{gathered}
$$




\subsection{Government}

Government expenditures are equal to $g_{t}$, and are financed by income taxes, by money creation and by issuance of one-period, nominally risk free bonds. The government flow budget constraint is then given by

$$
R_{t-1} \frac{B_{t-1}}{P_{t}}+g_{t}+t_{t}=\tau_{t}^{l} w_{t} l_{t}^{d}+\tau_{t}^{k}\left[\left(r_{t}^{k}-\delta\right) k_{t-1}\right]+\frac{M_{t}-M_{t-1}}{P_{t}}+\frac{B_{t}}{P_{t}}
$$

The debt consolidation experiment is defined as a sequence of public consumption, tax and inflation rates that allow to achieve in each period a reduction in the debt-to-GDP ratio, $\frac{B_{t}}{P_{t} y_{t}}$, such that a $20 \%$ reduction is obtained over a 10-year horizon. This implies that dynamics for real debt, $b_{t}$, is defined as follows

$$
\frac{b_{t}}{y_{t}}=\frac{b_{t-1}}{y_{t-1}}-\rho^{b} ; 0<t \leq T
$$

where $b_{0}$ is set equal to $80 \%$ of pre-consolidation steady state GDP and $b_{T}$ is the post-consolidation amount of debt, equal to $60 \%$ of post-consolidation GDP. We set $T$ equal to 10 years, and set $\rho^{b}$ equal to 0.02 , such that the government achieves an equal reduction in the debt to GDP ratio each year during the consolidation period.

\section{Equilibrium and Ramsey policy}

\subsection{Competitive Equilibrium}

Definition 1 A competitive equilibrium is a set of plans

$$
\left\{c_{t}^{u}, c_{t}^{c}, c_{t}, l_{t}^{u}, l_{t}^{c}, l_{t}, \lambda_{t}^{u}, \lambda_{t}^{c}, m c_{t}, \pi_{t}, w_{t}, w_{t}^{u}, w_{t}^{c}, m_{t}^{u}, m_{t}^{c}, m_{t}, y_{t}, b_{t}, R_{t}, k_{t}, r_{t}^{k}, \tau_{t}^{k}, \tau_{t}^{l}, g_{t}\right\}_{t=0}^{\infty},
$$

that, given initial values $\left\{m_{-1}^{u}, m_{-1}^{c}, m_{-1}, b_{-1}, k_{-1}\right\}$ satisfies equations (5), (8), (11), (10), (12), (9), (7), (10), (14), (16), (17), (20), (21), (22), (28), (23), (24), (27), and the debt-consolidation rule (29). ${ }^{5}$

\subsection{Ramsey Optimal Policy}

Definition 2 A Ramsey optimal policy is a competitive equilibrium that attains the maximum of the following additive social welfare function

$$
W=E_{0} \sum_{t=0}^{\infty} \beta^{t}\left[(1-\theta) u\left(c_{t}^{u}, l_{t}^{u}, g_{t}^{u}\right)+\theta u\left(c_{t}^{c}, l_{t}^{c}, g_{t}^{i}\right)\right]
$$

The Ramsey program is non-stationary because in the first period an incentive exists for the planner to generate inflation or tax "surprises". Following the literature we assume the planner does not engage in such policies (Schmitt-Grohé and Uribe, 2004a). ${ }^{6}$

\footnotetext{
${ }^{5}$ The competitive equilibrium must also satisfy the no-Ponzi game condition and the non-negativity constraint $R_{t} \geq 1$.

${ }^{6}$ Since the analytical derivation of the first order conditions of the Ramsey plan is cumbersome, we compute them using symbolic Matlab routines. The steady state of the Ramsey program is obtained using the OLS approach suggested in Schmitt-Grohé and Uribe (2011). Dynamics of the Ramsey plan around the steady state are computed using Dynare.
} 


\section{Ramsey Steady State}

The time unit is a year ${ }^{7}$ and we set the subjective discount rate $\beta$ to 0.96 to be consistent with a steady-state real rate of return of $4 \%$ per year. As Erosa and Ventura (2002), we set $\alpha$ to $64 \%$ and $\delta$ to $8 \%$. Parameters concerning monopolistic competition in the goods and labor market, nominal rigidities, the transaction technology and the share of public consumption over GDP in steady state are set following Schmitt-Grohé and Uribe (2004a). $\rho$ and $\rho_{w}$ are such that in the goods and labor markets monopolistic competition implies a gross markups of 1.2 under flexible prices and nominal wages. The annualized Rotemberg price and wage adjustment $\operatorname{costs}\left(\xi_{p}\right.$ and $\left.\xi_{w}\right)$ are 4.375 . Monetary transaction cost parameters $A$ and $B$ are set at 0.011 and 0.075 respectively, and steady state public consumption is $19 \%$ of GDP. The fraction of constrained households, $\theta$, is set at 0.5 .

Table 1 reports parameter values:

\begin{tabular}{ccl}
\hline \hline \multicolumn{2}{c}{ Parameters } & \multicolumn{1}{c}{ Description } \\
\hline \hline$\beta$ & 0.96 & Discount Factor \\
$\alpha$ & $0.64-1$ & Capital Share \\
$\delta$ & 0.08 & Depreciation Rate \\
$A$ & 0.011 & Trans. Cost Parameter \\
$B$ & 0.075 & Trans. Cost Parameter \\
$\rho$ & $1 / 1.2$ & Inverse Price Mark-up \\
$\rho_{w}$ & $1 / 1.2$ & Inverse Wage Mark-up \\
$\xi_{p}$ & 4.375 & Rotemberg Par. on Prices \\
$\xi_{w}$ & 4.375 & Rotemberg Par. on Wages \\
$\theta$ & 0.5 & Share of constrained households \\
$g$ & $0.19 y$ & Pre-consolidation Public Consumption over GDP \\
$b_{0}$ & $0.8 y$ & Pre-consolidation Public Debt/GDP \\
$b_{T}$ & $0.6 y$ & Post-consolidation Public Debt/GDP \\
\hline \hline
\end{tabular}

Table 1: Calibration

Table 2 summarizes our results about steady state outcomes. In particular, we report the preand post-consolidation steady state values for the policy variables and for individual consumption and leisure levels.

\footnotetext{
${ }^{7}$ In setting the time unit to be a year, we follow the literature. See, e.g., Schmitt-Grohé and Uribe (2004a). Tax rate adjustments require a political process that may take time. As a consequence, it may be difficult to change them at quarterly frequency. We feel one year is a much more realistic time lenght. No fundamental result of the paper depends on this assumption.
} 


\begin{tabular}{l|c|c|c|c}
\hline \hline & \multicolumn{2}{|c|}{ Baseline Model } & \multicolumn{2}{c}{ Inflation Targeting Model } \\
\cline { 2 - 5 } & Pre-Cons & Post-Cons. & Pre-Cons & Post-Cons. \\
\hline \hline Tax rate & $33.09 \%$ & $32.10 \%$ & $33.85 \%$ & $32.0 .3 \%$ \\
Gross Inflation rate & 1.70 & 1.42 & 1.7 & 1.7 \\
Unconstrained Consumption & 0.2848 & 0.2877 & 0.2813 & 0.2878 \\
Constrained Consumption & 0.1104 & 0.1127 & 0.1087 & 0.1128 \\
Aggregate Consumption & 0.1976 & 0.2002 & 0.1950 & 0.2003 \\
Constrained labour Effort & 0.2051 & 0.2050 & 0.2 & 0.2051 \\
Unconstrained labour Effort & 0.2013 & 0.2064 & 0.2051 & 0.3203 \\
Aggregate labour Effort & 0.2032 & 0.2057 & 0.2026 & 0.2059 \\
\hline \hline
\end{tabular}

Table 2: Pre and Post consolidation outcomes

The pre-consolidation inflation rate is $1.7 \%$. Menna and Tirelli (2013) show that LAMP causes an increase in the optimal inflation rate relative to the representative agent (RA) model. This happens because the planner exploits the inflation tax to lower the income tax rate, thus redistributing income from unconstrained to constrained households. We obtain an identical result here: under the RA model pre-consolidation inflation is $0.41 \%$. After consolidation the income tax is reduced by one percentage point and the optimal inflation rate falls to $1.45 \%$. This happens because after the consolidation lower revenues are sufficient to balance the budget and because the consolidation per se redistributes incomes towards constrained households and the incentive to exploit inflation as a redistributive tool is therefore reduced.

\section{Tax and inflation during the transition. Optimal dynamics vs pure inflation targeting}

Figure 1 shows transition dynamics under LAMP and under the representative agent assumption. Consider this latter case first. The Ramsey planner immediately raises taxes by up to 5 percentage points and, to a more limited extent, lowers public expenditures. This tax-expenditure mix is obviously driven by the importance of public goods in households preferences. In addition, the planner chooses a persistent fall in the real interest rate, allowing a substantial increase in inflation, that after 3 years reaches a peak of $2 \%$ above the initial steady state. The mix of contractionary fiscal policies, low real interest rates and high inflation is very persistent. After 10 years the tax rate is still above the initial steady state and public spending-to-GDP remains below it. The surge in inflation is slightly less persistent. The tax increase causes a reduction in disposable income but, in spite of the real interest rate fall, the amount of consumption smoothing is limited. In fact consumption falls by more than investment. This is the consequence of the adverse effect of inflation-induced monetary transaction costs, that operate as a sort of consumption tax. Overall the consolidation causes a large and persistent fall in output. Output rises above the pre-consolidation level only after 12 years. 

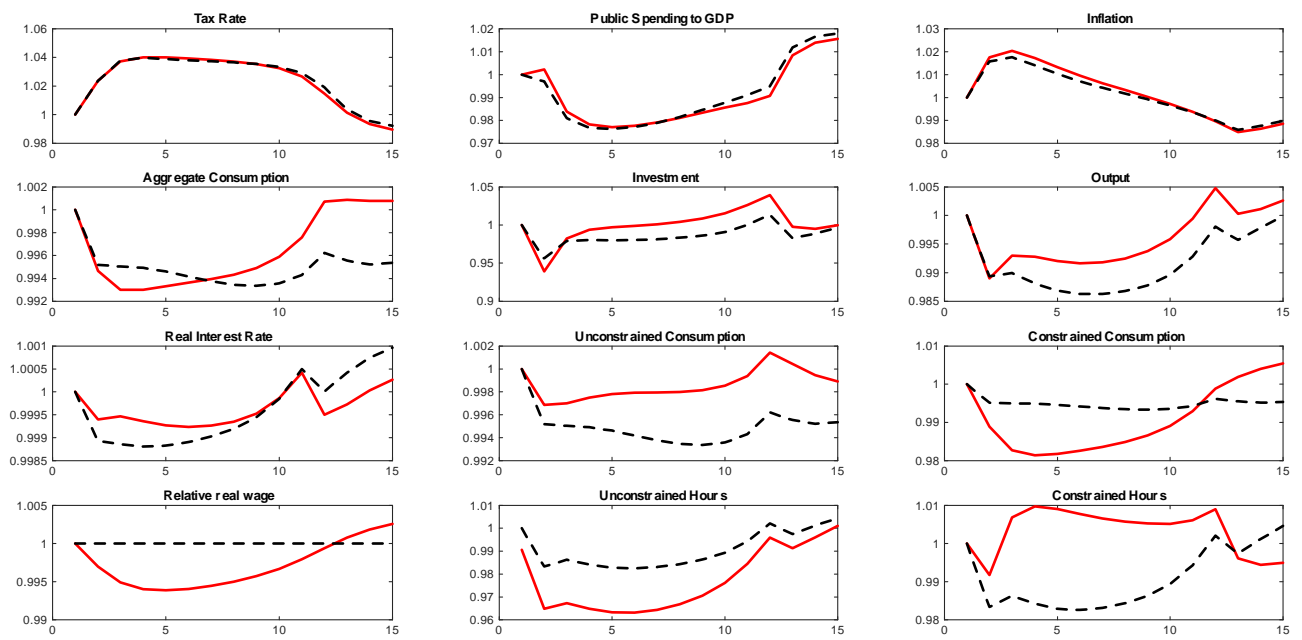

Fig. 1: Lamp baseline model (solid line) versus Rapresentative model (dashed line)

Comparison between the LAMP and the representative agent models shows that very small differences arise both in the use of policy tools and in the dynamics of aggregate variables. However, the two household groups react quite differently to the policy actions. Ricardian households reduce investment as much as in the RA case. This frees resources for their consumption smoothing but, relative to the RA case, such resources now benefit a much smaller number of households. As a result, wealthy Ricardian households stabilize their consumption far more than they would do in absence of constrained households. In addition, they sharply reduce their labor supply relative to the RA case. To the contrary, constrained households raise their labor supply and sharply reduce consumption. Thus, the possibility of depleting their real money holding proves a poor substitute for the physical capital holdings that Ricardian households exploit to stabilize their consumption. These results suggest that concern for redistribution, which plays an important role in determining steady state outcomes, does not significantly affect the choice of policies during the transition.

Figure 2 shows the implications of an alternative strategy of debt reduction, entirely based on tax and public expenditure variations, whereas the Central Bank sticks to a "pure" inflation targeting strategy. ${ }^{8}$

\footnotetext{
${ }^{8}$ To facilitate the comparison between alternative scenarios we assume that in this case the Central Bank inflation target is $1.7 \%$, as in the pre-consolidation scenario under Ramsey-optimal consolidation policies.
} 

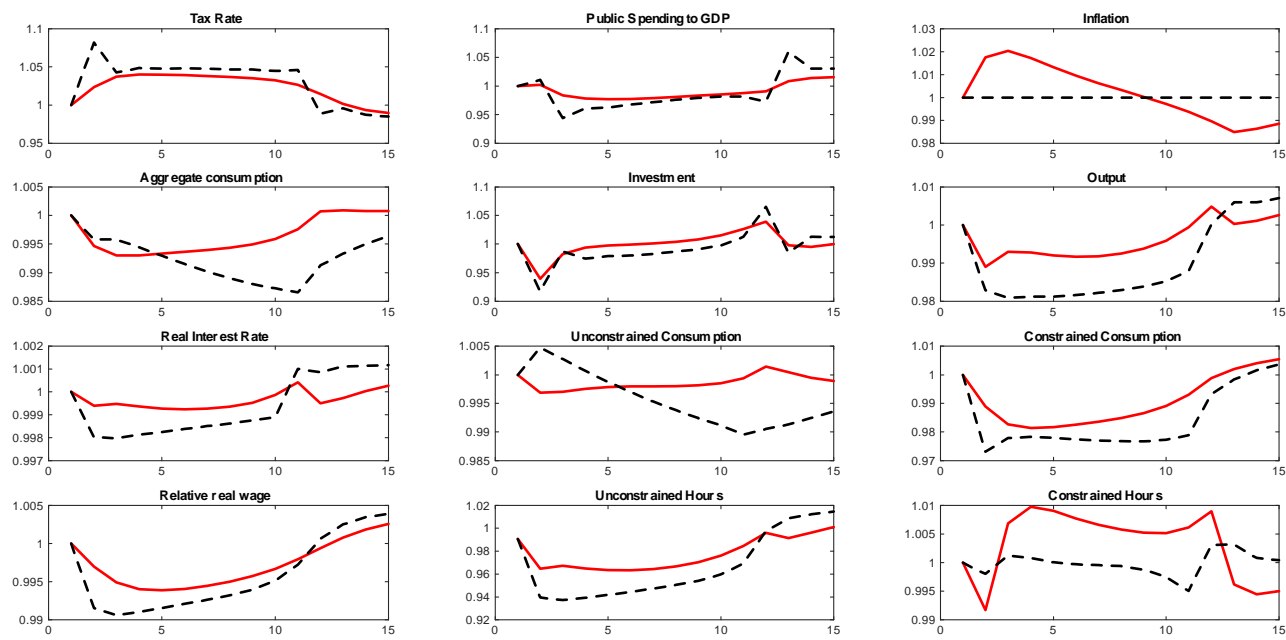

Fig. 2: Lamp Baseline model (solid line) versus Pure Inflation Targeting (dashed line)

The combination of fiscal contractionary stimuli is much stronger during the first three years. The output contraction is deeper and more persistent, due to the lack of monetary stimulus. To stabilize inflation the Central bank must lower real interest rates well below the baseline model case. After the first two years real interest rates begin to gradually increase. Ricardian households are therefore induced to initially raise their consumption. This outcome is gradually reversed when the real interest rate begins to rise. Higher income taxes obviously reduce returns from labor. Higher consumption raises their marginal rate of substitution between consumption and leisure. As a result, they substantially reduce their labor supply. Pure inflation targeting also bears strong implications for constrained households. in fact, absent the inflation surge that characterizes the optimal policy, their consumption substantially falls relative to the baseline scenario. ${ }^{9}$ Given the choice of lower consumption levels during the transition, their labor supply remains relatively stable. To conclude discussion of this case, note that, relative to the optimal policy, "pure" inflation targeting causes a large and persistent additional output loss.

\footnotetext{
${ }^{9}$ Some intertemporal dynamics do take place even in this case because of dynamics in monetary transaction costs (see eq. 14).
} 

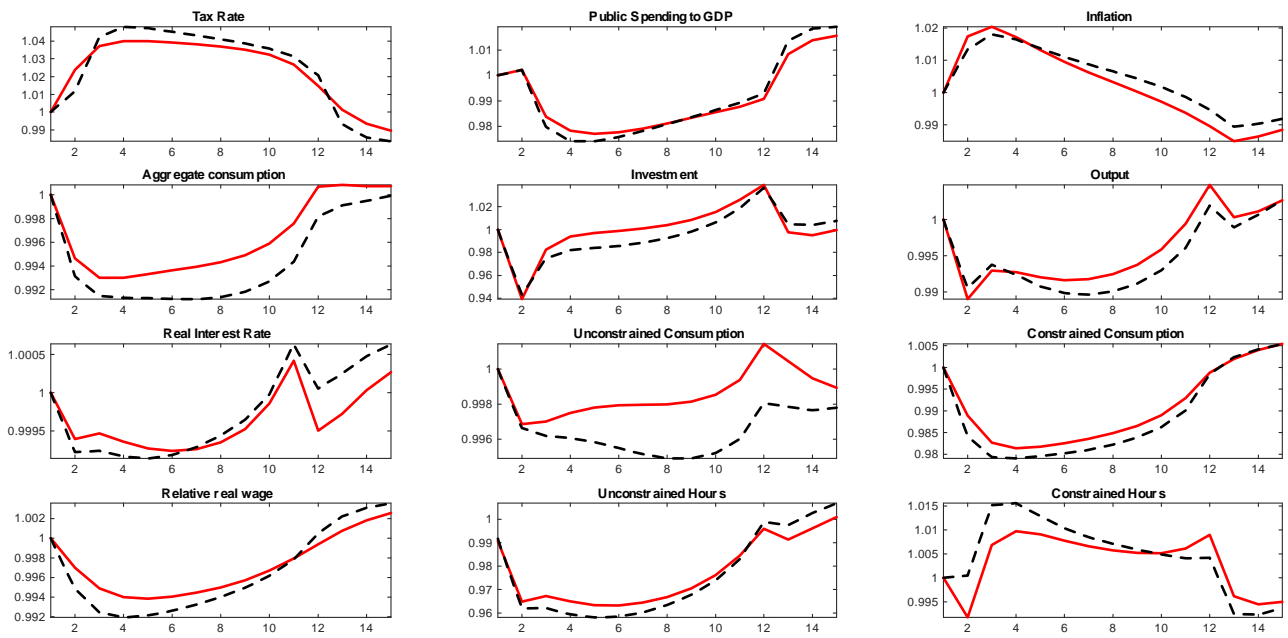

Fig. 3: Rot model (dashed line) versus Lamp Baseline model (solid line)

Finally, Figure 3 allows to analyze a situation where constrained households behave like traditional Rule-of-thumb households, i.e. they do not exploit their money holdings as a buffer to stabilize consumption as in Galì et al. (2007). Transition dynamics for inflation and the fiscal variables are marginally affected. Constrained households now can only rely on their wage-setting decisions to smooth consumption. As a result, in spite of the relative increase in their labor supply, their consumption falls more strongly.

\subsection{Optimal dynamics under a different labor market characterization}

So far we have assumed that households supply a differentiated labor type and therefore act as wage setters. Other contributions to the LAMP literature typically postulate that households supply the whole labor bundle and wage setting decisions for each labor type $j$ are therefore entrusted to a monopolistic trade union (Galì et al., 2004, 2007; Colciago, 2011; Motta and Tirelli, 2012). At the given wage $w_{t}(j)$ each household then supplies on demand the labor type $j$. In this case it is assumed that the two household groups are uniformly distributed across unions, and demand for each labour type is uniformly distributed across households. Households therefore work the same amount of time. Each labor union maximizes a weighted average of the lifetime utility of its members subject to their budget constraints:

$$
E_{0} \sum_{t=0}^{\infty} \beta^{t}\left[(1-\theta) u\left(c_{t}^{u}, l_{t}\right)+\theta u\left(c_{t}^{c}, l_{t}\right)\right] .
$$

In Figure 4 we compare transition dynamics under the two labor market characterizations. Relative to the benchmark case, "unionization" of the wage policy produce a wage rate which is too high for constrained households and too low for Ricardian households. As a result consumption of 
non-Ricardian household is dramatically reduced throughout the transition, whereas the opposite holds true for unconstrained households. The planner's incentive to inflate is certainly reduced. To rationalize this result bear in mind that consumption of non Ricardian households has been penalized by the union common wage policy, and higher inflation would further tax their consumption, the planner is therefore induced to choose a mix of higher taxes - that mainly fall on Ricardian labor incomes - and (to a lesser extent) greater public expenditures that support labor demand and contained households' incomes and consumption.
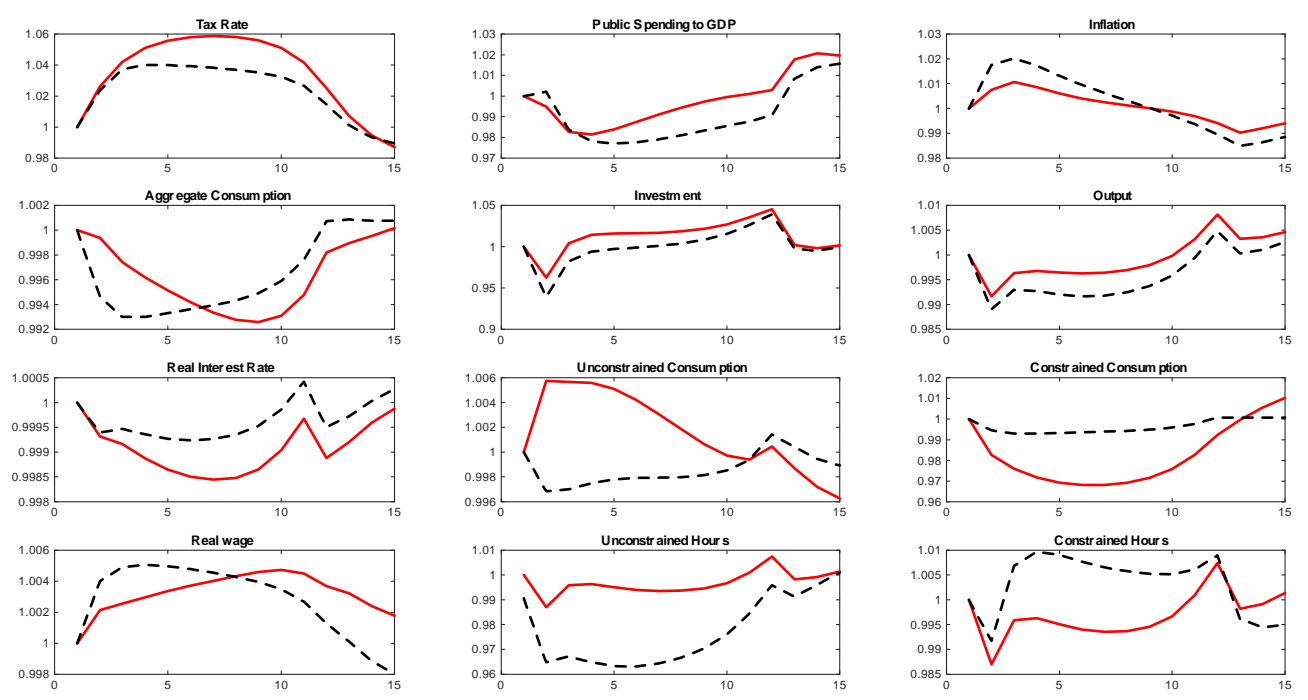

Fig. 4: Heterogeneity (dashed line) versus case homogeneity in the number of working hours (solid line)

\section{Conclusions}

In this paper we identify the optimal policy mix for income taxes, public expenditures and inflation designed to achieve an exogenous debt reduction path. The optimal policy envisages persistent reductions in public consumption and increases in taxes and inflation. A persistent fall in consumption and investment cannot be avoided, and households that cannot exploit financial markets to smooth their consumption bear the brunt of adjustment costs.

One key message is that an integrated package of fiscal and monetary policies may prove quite beneficial relative to a situation where the Central Bank is only concerned with inflation stability and the inflation target is defined as a ceiling, as in the Eurozone, where the ECB has repeatedly justified expansionary monetary policies on the grounds that inflation was below target. In fact the fiscal consolidation would require far more aggressive monetary policies, accepting that inflation overshoots the target for a prolonged period. As a matter of fact our results emphasize important 
shortcomings in the EMU system of economic governance, which utterly neglects the desirability of coordinated fiscal and monetary policy actions. In this context such coordination would entail a great deal of flexibility in the inflation target choice, based on the explicit recognition that accommodative monetary policies provide an essential contribution to limit the undesirable effects of fiscal consolidations. 


\section{References}

Alesina, Alberto \& Favero, Carlo \& Giavazzi, Francesco, 2015. "The output effect of fiscal consolidation plans," Journal of International Economics, Elsevier, vol. 96(S1)

Blanchard, O., Dell'Ariccia, G., and Mauro, P., 2010. Rethinking macroeconomic policy. IMF Staff Position Note, February 12.

Coenen, Günter \& Mohr, Matthias \& Straub, Roland, 2008. "Fiscal consolidation in the euro area: Long-run benefits and short-run costs," Economic Modelling, Elsevier, vol. 25(5), pages 912-932, September.

Colciago, A., 2011. "Rule-of-Thumb Consumers Meet Sticky Wages," Journal of Money, Credit and Banking, Blackwell Publishing, vol. 43, pages 325-353, 03.

Correia, I., 2010. "Consumption taxes and redistribution," The American Economic Review, 100 vol. 4, pages 1673-1694.

European Commission, http://ec.europa.eu/economy_finance/economic_governance/sgp/index_en.htm

Fall, F. and J. Fournier (2015), "Macroeconomic uncertainties, prudent debt targets and fiscal rules", OECD Economics Department Working Papers, No. 1230, OECD Publishing, Paris. http://dx.doi.org/10.1787/5jrxv0bf2vmx-en

Ferrara, M. \& Tirelli, P., 2014. "Fiscal Consolidations: Can We Reap the Gain and Escape the Pain?," Working Papers 283, University of Milano-Bicocca, Department of Economics, revised Oct 2014 .

Forni, L. \& Gerali, A. \& Pisani, M., 2010. "Macroeconomic Effects Of Greater Competition In The Service Sector: The Case Of Italy," Macroeconomic Dynamics, Cambridge University Press, vol. 14(05), pages 677-708, November.

Friedman, M. (1969). "The optimum quantity of money." in The optimum Quantity of money and other essays, Chicago, Aldine.

Fuest, C., Spengel, C., Finke, K., Heckemeyer, J., Nusser, H., (2013). "Profit shifting and 'aggressive' tax planning by multinational firms: Issues and options for reform," ZEW Discussion Papers 13-044, ZEW - Zentrum für Europäische Wirtschaftsforschung / Center for European Economic Research.

Galbraith, J.K., Giovannoni, O. and Russo, A.J. (2007). "The Fed's Real Reaction Function: Monetary Policy, Inflation, Unemployment, Inequality-and Presidential Politics." Economics Working Paper Archive wp_511, Levy Economics Institute.

Galí J, López-Salido D, Vallés J, 2004. Rule-of-thumb consumers and the design of interest rate rules, Journal of Money, Credit and Banking 36, 739-764.

Galí, J., López-Salido, J.D. and Vallés, J. (2007). "Understanding the Effects of Government Spending on Consumption." Journal of the European Economic Association, MIT Press, vol. 5(1), pages 227-270, 03 . 
Giannoni Marc P. \& Woodford, Michael 2003. "Optimal Interest-Rate Rules: I. General Theory", NBER Working Papers 9419, National Bureau of Economic Research, Inc.

Guerron-Quintana, P.A. (2009). "Money demand heterogeneity and the great moderation." Journal of Monetary Economics, 56: 255-266.

Heathcote, J., Perri, F., and Violante, G. L,( 2009). "Unequal We Stand: An Empirical Analysis of Economic Inequality in the United States, 1967-2006," Review of Economic Dynamics, Elsevier for the Society for Economic Dynamics, vol. 13(1), pages 15-51, January.

Krusell, P., Quadrini, V., \& Rios-Rull, J. V. (1996). Are consumption taxes really better than income taxes?. Journal of Monetary Economics, 37(3), 475-503.

Motta G, Tirelli P, 2012. Optimal Simple Monetary and Fiscal Rules under Limited Asset Market Participation, Journal of Money, Credit and Banking, Blackwell Publishing, vol. 44(7), pages 1351-1374, October.

OECD 2012, "Fiscal Consolidation: How Much is Needed to Reduce Debt to a Prudent Level?", OECD Economics Department Policy Notes, No. 11, April.

Nickel, Christiane \& Rother, Phillipp \& Zimmermann, Lilli, 2010. "Major public debt reductions. Lessons from the past, lessons for the future", Working Paper Series 1241, European Central Bank.

OECD (2013), "How much scope for growth and equity-friendly fiscal consolidation?", OECD Economics Department Policy Notes, No. 20 July 2013.

Perotti, Roberto 2011, "The 'Austerity Myth': Gain Without Pain?" NBER Working Paper No. 17571 (Cambridge, Massachusetts: National Bureau of Economic Research).

Phelps, E.S. (1973). "Inflation in the theory of public finance." The Swedish Journal of Economics, 75: $67-82$.

Philippopoulos, A., et al., Optimal fiscal and monetary policy action in a closed economy, Econ. Model. (2014), http://dx.doi.org/10.1016/j.econmod.2014.10.045

Rotemberg, J.J. (1982). "Sticky prices in the United States." Journal of Political Economy, 90: $1187-1211$.

Saez, E. (2004) "Reported Incomes and Marginal Tax Rates, 1960-2000: Evidence and Policy Implications." in James Poterba, ed., Tax Policy and the Economy, 18: 117-174.

Saez, E., Slemrod, J. and Giertz, S. (2012). "The Elasticity of Taxable Income with Respect to Marginal Tax Rates: A Critical Review." Journal of Economic Literature 50(1), 3-50.

Saez, E., and Zucman, G. (2014). "Wealth inequality in the United States since 1913: Evidence from capitalized income tax data (No. w20625)." National Bureau of Economic Research.

Schmitt-Grohé, S. and Uribe, M. (2004a). "Optimal fiscal and monetary policy under sticky prices," Journal of Economic Theory, 114: 198-230. 
Schmitt-Grohé, S. and Uribe, M. (2006). "Optimal fiscal and monetary policy in a medium-scale macroeconomic model." in Gertler M. and K. Rogoff (eds.), NBER, Macroeconomics Annual 2005, Cambridge, MIT Press: 383-425.

Schmitt-Grohé, S. and Uribe, M. (2011). "The optimal rate of inflation." in Friedman B.M. and M. Woodford (eds.), Handbook of Monetary Economics, Elsevier, Amsterdam: 723-828.

Schmitt-Grohé, S. and Uribe, M. (2011). "An OLS approach to computing Ramsey equilibria in medium-scale macroeconomic models." Economics Letters, Volume 115, Issue 1, April 2012, Pages 128-129.

Sims, C.A. (1994). "A simple model for study of the determination of the price level and the interaction of monetary and fiscal policy." Economic Theory, 4: 381-399.

Slemrod, J and Yitzhaki, S. (2002). "Tax Avoidance, Evasion and Administration." In Handbook of Public Economics, 1st edition, Volume 3, eds. Alan Auerbach and Martin Feldstein, 1423-1470. Amsterdam: North-Holland. 